\title{
PENGARUH PROFITABILITAS, SOLVABILITAS, DAN UKURAN PERUSAHAAN TERHADAP AUDIT DELAY DENGAN REPUTASI KAP SEBAGAI PEMODERASI
}

\author{
Ruth Elvienne \\ Prima Apriwenni* \\ Program Studi Akuntansi, Kwik Kian Gie School of Business, Jl. Yos Sudarso Kav. 87, Jakarta 14350
}

\begin{abstract}
Financial statements are an instrument for companies in providing various information and company performance to those who have interests. Financial reports must be reported on time. The length of time the audit is completed by the auditor can cause audit delay. Therefore, the purpose of this study is to determine the effect of profitability, solvency, firm size on audit delay with the reputation of KAP as a moderating variable. The theory in this study uses agency theory and signal theory. The object of this research are 10 mining companies listed on the Indonesia Stock Exchange in 20162018. The sampling technique used is the Non-Probability Sampling technique, using a purposive sampling method. The results of this study indicate that solvency has a positive and significant effect on audit delay and the reputation of KAP is able to strengthen the relationship of profitability to audit delay.
\end{abstract}

Keywords: Audit Delay, Profitability, Solvability, Company Size, Reputation of Public Accountant Firm.

\begin{abstract}
Abstrak
Laporan keuangan merupakan instrumen bagi perusahaan dalam menyanpaikan berbagai informasi serta kinerja perusahaan pada para pihak yang memiliki kepentingan. Laporan keuangan harus dilaporkan tepat waktu. Lamanya waktu penyelesaian audit yang dilakukan oleh auditor dapat menyebabkan terjadinya audit delay. Oleh karena itu, tujuan dari penelitian ini adalah untuk mengetahui pengaruh profitabilitas, solvabilitas, ukuran perusahaan terhadap audit delay dengan reputasi KAP sebagai variabel pemoderasi. Teori dalam penelitian ini menggunakan teori agensi dan teori sinyal. Objek penelitian ini adalah 10 perusahaan pertambangan yang terdaftar di BEI tahun 2016-2018. Teknik pengambilan sampel yang digunakan adalah teknik Non-Probability Sampling, menggunakan metode purposive sampling. Hasil dari penelitian ini menunjukkan bahwa solvabilitas berpengaruh positif dan signifikan terhadap audit delay dan reputasi KAP mampu memperkuat hubungan profitabilitas terhadap audit delay.
\end{abstract}

Kata kunci: Audit Delay, Profitabilitas, Solvabilitas, Ukuran Perusahaan, Reputasi KAP

\section{Pendahuluan}

Semakin berkembangnya dunia usaha di Indonesia menyebabkan perusahaanperusahaan besar membutuhkan sumber pendanaan dari luar. Salah satu sumber tersebut adalah penerbitan saham kepada masyarakat luas, yang disebut dengan go public.

\footnotetext{
*Alamat kini: Institut Bisnis dan Informatika Kwik Kian Gie, Jl. Yos Sudarso Kav. 87, Jakarta 14350

Penulis untuk Korespondensi: Telp. (021) 65307062 Ext. 708, Email: prima.apriwenni@kwikkiangie.ac.id
} 
Pelaksanaan audit yang semakin sesuai dengan standar membutuhkan waktu tidak sedikit, bahkan terkadang auditor menunda publikasi laporan audit apabila dirasa perlu untuk memperpanjang masa audit agar informasi keuangan yang disampaikan relevan dan dapat diandalkan. Lamanya waktu penyelesaian audit yang dilakukan oleh auditor dapat menyebabkan terjadinya audit delay. Audit delay adalah lamanya penyelesaian audit dari tanggal tutup buku laporan keuangan sampai tanggal laporan audit dipublikasikan di BEI. Rentang waktu dalam perusahaan go public atau emiten yang efeknya terdaftar di Bursa Efek Indonesia (BEI) mencakup jumlah hari antara tanggal laporan keuangan sampai tanggal penerimaan laporan dipublikasikan di bursa yang disebut dengan istilah total lag.

Laporan keuangan tahunan berguna bagi pihak-pihak yang berkepentingan terhadap informasi laporan keuangan, seperti manajemen, investor, kreditor, dan pemerintah karena laporan keuangan suatu perusahaan memuat informasi mengenai laba yang dihasilkan oleh perusahaan, dimana hal tersebut merupakan salah satu dasar dalam pengambilan keputusan untuk membeli atau menjual kepemilikan yang dimiliki oleh investor.

Menurut Keputusan Ketua BAPEPAM No. Kep-346/BL/2011, Peraturan X.K.2 tentang Penyampaian Laporan Keuangan Berkala Emiten atau Perusahaan Publik, menyatakan laporan keuangan berkala disertai dengan Laporan Akuntan disampaikan kepada BAPEPAM selambatlambatnya pada akhir bulan ketiga setelah tanggal laporan keuangan tahunan. Apabila perusahaan terlambat dalam menyelesaikan laporan keuangannya maka akan dikenakan sanksi administrasi dan denda. Namun, selama tahun 2014, terdapat 49 emiten yang terlambat melaporkan laporan keuangannya (Investasi Kontan, 2014). Selain itu, pada tahun 2016 BEI melaporkan terdapat 63 emiten yang mengalami keterlambatan penyampaian laporan keuangan auditan tahun 2015 (Liputan6, 2016), serta di tahun 2015 dimana tercatat 52 emiten yang mengalami keterlambatan penyampaian laporan auditan tahun 2014 (Harian Ekonomi Neraca, 2015), dan kebanyakan dari perusahaan yang mengalami keterlambatan pengumpulan laporan keuangan hingga harus mengalami suspensi berasal dari sektor pertambangan. Fenomena ini sebaiknya dijadikan pembelajaran bagi setiap perusahaan agar menyampaikan laporan keuangan sesuai batas waktu yang telah ditentukan sehingga tidak memperoleh sanksi administratif.

Beberapa faktor yang diindikasikan dapat memengaruhi audit delay dalam penelitian terdahulu antara lain: Profitabilitas, Solvabilitas, Ukuran Perusahaan, dan Reputasi Kantor Akuntan Publik. Faktorfaktor tersebut perlu diperhatikan secara seksama agar publikasi laporan keuangan yang telah diaudit menjadi tepat waktu.

Profitabilitas merupakan kemampuan perusahaan dalam menghasilkan laba dari kegiatan operasinya. Perusahaan dengan profitabilitas tinggi cenderung membutuhkan waktu pengauditan laporan keuangan yang lebih cepat karena adanya tuntutan untuk menyampaikan kabar baik tersebut secepatnya kepada publik. Penelitian yang dilakukan oleh Lianto dan Kusuma, (2010) menyatakan bahwa profitabilitas berpengaruh terhadap audit delay. Sebaiknya, menurut penelitian Rachmawati, (2008) menemukan bahwa profitabilitas tidak berpengaruh terhadap audit delay perusahaan.

Solvabilitas adalah pengukuran kemampuan perusahaan untuk memenuhi kewajiban keuangan, baik kewajiban keuangan jangka pendek maupun jangka panjang. Proses pengauditan utang relatif membutuhkan waktu yang lebih lama dibandingkan pengauditan ekuitas, khususnya apabila jumlah debtholder-nya banyak. Penelitian yang dilakukan oleh Ningsih \& Widhiyani (2015) menjelaskan bahwa solvabilitas berpengaruh positif signifikan terhadap audit delay pada perusahaan manufaktur yang terdaftar di BEI tahun 20112013. Sedangkan hasil penelitian yang didapat oleh Anggradewi \& Haryanto, (2014) menyatakan hal yang sebaliknya yaitu bahwa solvabilitas tidak memiliki pengaruh terhadap audit delay.

Ukuran perusahaan merupakan besar kecilnya perusahaan yang dapat diukur melalui nilai-nilai yang terdapat dalam laporan keuangan, salah satunya adalah besar kecilnya total aset yang dimiliki oleh perusahaan tersebut. Penelitian yang dilakukan oleh Puspitasari dan Sari, (2012) 
menunjukkan bahwa total aset mempunyai pengaruh positif dan signifikan terhadap audit delay. Namun ada perbedaan dengan penelitian Kartika, (2009) yang menyatakan bahwa ukuran perusahaan mempunyai pengaruh negatif dan signifikan terhadap audit delay. Semakin besar total aset yang dimiliki oleh suatu perusahaan maka semakin kecil audit delay-nya.

Reputasi Kantor Akuntan Publik adalah kualitas yang dimiliki KAP dimana dapat dilihat dari ukuran besar atau kecilnya KAP tersebut. Terkait untuk meningkatkan kredibilitas laporan maka perusahaan menggunakan jasa KAP dengan reputasi yang baik. Hal itu ditunjukkan dengan kantor akuntan publik yang berafiliasi dengan KAP besar yang dikenal dengan nama Big Four. Berdasarkan penelitian Lucyanda \& Nura'ni, (2013), reputasi KAP berpengaruh negatif terhadap audit delay, namun berbeda dengan penelitian Angruningrum \& Wirakusuma, (2013) yang menyatakan reputasi KAP tidak berpengaruh terhadap audit delay. Jika reputasi KAP merupakan variabel pemoderasi, maka menurut penelitian Murti \& Widhiyani, (2016), reputasi KAP memperlemah pengaruh ukuran perusahaan terhadap audit delay tetapi mampu memperkuat hubungan antara profitabilitas terhadap audit delay, yaitu sama-sama memperpendek audit delay. namun dalam penelitian Handayani \& Wirakusuma, (2013) reputasi KAP mampu memperlemah hubungan profitabilitas terhadap audit delay dan memperkuat hubungan solvabilitas terhadap audit delay.

\section{Landasan Teori}

\section{Teori Keagenan (Agency Theory)}

Teori agensi adalah teori yang menjelaskan hubungan antara manajemen (agen) dan pemilik (principal) (Jensen \& Meckling, 1976). Implementasi teori agensi dapat berupa kontrak kerja yang mengatur pembagian hak dan kewajiban masing-masing pihak sesuai dengan porsinya. Agen memiliki kewajiban untuk bertindak menggunakan cara yang sesuai dengan kepentingan prinsipal. Di sisi lain, prinsipal juga memiliki kewajiban untuk memberikan insentif yang layak kepada agen sesuai dengan haknya. Audit delay tidak dapat dipisahkan dari teori agensi. Audit delay berhubungan erat dengan ketepatan waktu dalam mempublikasikan laporan keuangan, apabila informasi tersebut tidak disampaikan tepat waktu akan menyebabkan nilai dari informasi dalam laporan keuangan tersebut menjadi berkurang. Indikasi audit delay bagi pihak perusahaan emiten adalah diperlukannya biaya agensi untuk mengembalikan kepercayaaan investor seperti biaya untuk pengungkapan informasi tambahan, kaitannya adalah semakin panjang audit delay dan semakin sering audit delay terjadi maka akan semakin besar pula biaya agensi yang harus dikeluarkan.

Auditor merupakan pihak yang dianggap dapat menjembatani kepentingan pihak pemegang saham dengan pihak manajer. Teori agensi digunakan untuk membantu komite audit memahami konflik kepentingan yang dapat muncul antara pemilik dan manajemen. Sehingga diharapkan tidak terjadi kecurangan maupun kesulitan dalam penyusunan laporan keuangan yang dapat menimbulkan tenggang waktu, yaitu audit delay dalam kategori total lag yang berkepanjangan.

\section{Signaling Theory}

Signalling Theory yang dikemukakan oleh Ross, (1977), menyatakan bahwa pihak eksekutif perusahaan yang memiliki informasi lebih baik mengenai perusahaannya akan terdorong untuk menyampaikan informasi tersebut kepada calon investor agar harga saham perusahaannya meningkat. Teori sinyal menekankan kepada pentingnya informasi yang dikeluarkan oleh perusahaan terhadap keputusan investasi pihak di luar perusahaan. Informasi merupakan unsur penting bagi investor dan pelaku bisnis karena informasi pada hakekatnya menyajikan keterangan, catatan atau gambaran baik untuk keadaan masa lalu, saat ini maupun keadaan masa yang akan datang bagi kelangsungan hidup suatu perusahaan. Informasi yang lengkap, relevan, akurat dan tepat waktu sangat diperlukan oleh investor di pasar modal sebagai alat analisis untuk mengambil keputusan investasi.

Asumsi dari teori sinyal ini memberikan ruang bagi investor untuk mengetahui bagaimana keputusan yang akan diambilnya berkaitan dengan nilai perusahaan tersebut. Akibatnya, ketika rasio profitabilitas, solvabilitas, dan ukuran perusahaan 
menunjukkan nilai yang berubah, hal ini otomatis memberikan informasi pada investor dalam memberikan penilaian terhadap perusahaan.

\section{Audit Delay}

Menurut Dyer \& McHugh, (1975), ada tiga kriteria keterlambatan pelaporan keuangan dalam penelitiannya: Preliminary lag adalah interval antara berakhirnya tahun fiscal sampai dengan tanggal diterimanya laporan keuangan pendahulu oleh pasar modal, Auditor's signature lag adalah interval antara berakhirnya tahun fiskal sampai tanggal yang tercantum di dalam laporan auditor. Dari definisi tersebut auditor's signature lag merupakan salah satu nama lain dari audit delay, Total Lag adalah interval antara berakhirnya tahun fiskal sampai dengan tanggal diterimanya laporan keuangan tahunan publikasi oleh pasar modal.

Dalam penelitian ini, kriteria yang digunakan adalah total lag yang diukur berdasarkan interval jumlah hari tanggal laporan keuangan sampai tanggal penerimaan laporan dipublikasikan di bursa. Rentang waktu antara tanggal laporan keuangan perusahaan dan tanggal ketika informasi keuangan diumumkan ke publik sangat berpengaruh terhadap kualitas informasi laporan keuangan yang dilaporkan.

\section{Profitabilitas}

Menurut Asnawi \& Wijaya (2015), rasio profitabilitas menunjukkan kemampuan perusahaan mendapatkan hasil selama satu periode produksi. Kartika, (2009) menyatakan perusahaan tidak akan menunda penyampaian informasi yang berisi berita baik. Oleh karena itu, perusahaan yang mampu menghasilkan profit akan cenderung mengalami audit delay yang lebih pendek, sehingga good news tersebut dapat segera disampaikan kepada para investor dan pihak-pihak yang berkepentingan lainnya. Sebagai dasar pemikiran bahwa tingkat keuntungan dipakai salah satu cara untuk menilai keberhasilan efektivitas perusahaan. Perusahaan yang profitable memiliki insentif untuk menginformasikan ke publik kinerja unggul mereka dengan mengeluarkan laporan tahunan secara cepat.

\section{Solvabilitas}

Menurut Asnawi \& Wijaya, (2015) rasio solvabilitas menunjukkan kemampuan bayar untuk jangka panjang. Salah satu rasio solvabilitas adalah membandingkan besaran utang total dengan aktiva total. Perbandingan ini dikenal sebagai rasio utang (Debt Ratio). Menurut Ningsih \& Widhiyani, (2015) solvabilitas merupakan kemampuan suatu perusahaan untuk membayar seluruh kewajibannya. Besarnya rasio debt to total asset mengindikasikan besarnya resiko keuangan perusahaan yang mengakibatkan lamanya penyusunan laporan keuangan yang berdampak pada panjangnya penerbitan laporan keuangan perusahaan.

\section{Ukuran Perusahaan}

Ukuran perusahaan dapat dilihat dari seberapa banyak perusahaan tersebut mempunyai sejumlah informasi mengenai dirinya (kompleksitas operasional dan intensitas transaksi perusahaan) sehingga akan lebih banyak disorot oleh publik dibandingkan perusahaan yang berukuran kecil. Ukuran perusahaan dapat dihitung menggunakan total asset (LnSize). Total aset yang dimaksud adalah jumlah aset yang dimiliki perusahaan klien yang tercantum pada laporan keuangan perusahaan pada akhir periode yang telah diaudit (Estrini \& Laksito, 2013).

\section{Pengaruh Profitabilitas terhadap Audit Delay}

Rasio profitabilitas menunjukkan kemampuan perusahaan mendapatkan hasil selama satu periode produksi (Asnawi \& Wijaya, 2015). Profitabilitas yang tinggi menandakan kinerja yang baik, yang berarti kabar baik (good news) bagi pemegang saham sekaligus informasi baik mengenai kinerja manajemen sehingga perusahaan tidak akan menunda penampaian laporan keuangannya tersebut kepada publik. Signalling theory menyatakan bahwa perusahaan yang berkualitas baik dengan sengaja akan memberikan sinyal pada pasar dengan demikian pasar diharapkan dapat membedakan perusahaan yang berkualitas baik dan buruk. Rasio profitabilitas tinggi merupakan kabar baik bagi perusahaan. Berdasarkan signalling theory, perusahaan yang memiliki kabar baik (good news) akan 
menyampaikan laporan keuangan tepat waktu. Maka, semakin besar profitabilitas diduga audit delay akan semakin pendek.

$\mathrm{Ha}_{1}$ : Profitabilitas berpengaruh negatif terhadap audit delay.

\section{Pengaruh Solvabilitas terhadap Audit Delay}

Rasio solvabilitas menunjukkan kemampuan bayar untuk jangka panjang. Solvabilitas digunakan untuk mengukur sejauh mana aktiva perusahaan dibiayai dengan utang (Asnawi \& Wijaya, 2015). Ketika perusahaan memiliki jumlah proporsi hutang yang lebih banyak daripada jumlah ekuitas, maka auditor akan memerlukan waktu yang lebih banyak dalam mengaudit laporan keuangan perusahaan karena rumitnya prosedur audit akun hutang serta penemuan bukti- bukti audit yang lebih kompleks terhadap pihak-pihak kreditur perusahaan (Budiartha, 2014)

$\mathrm{Ha}_{2}$ : Solvabilitas berpengaruh positif terhadap audit delay.

\section{Pengaruh Ukuran Perusahaan terhadap Audit Delay}

Ukuran perusahaan dapat dinilai dari total asset yang dimiliki perusahaan. Perusahaan besar akan menyelesaikan proses auditnya lebih cepat dibandingkan perusahaan kecil, hal ini disebabkan oleh beberapa faktor yaitu manajemen perusahaan yang berskala besar cenderung diberikan insentif untuk mengurangi audit delay dikarenakan perusahaan tersebut dimonitor secara ketat oleh investor, pengawas permodalan, dan pemerintah. Perusahaan dengan total aset yang besar dan memiliki pengendalian internal yang kuat merupakan good news bagi perusahaan. Hal ini berkaitan dengan teori sinyal, bahwa perusahaan akan cenderung lebih cepat melaporkan laporan keuangannya apabila perusahaan memiliki good news.

$\mathrm{Ha}_{3}$ : Ukuran Perusahaan berpengaruh negatif terhadap audit delay.

\section{Pengaruh Reputasi KAP terhadap Audit Delay.}

Dalam meningkatkan kredibilitas dari laporan keuangan, perusahaan menggunakan jasa KAP yang memiliki reputasi atau kualitas KAP yang baik. Kualitas KAP dapat diketahui dari besarnya perusahaan audit yang melaksanakan pengauditan laporan keuangan tahunan. Menurut teori agensi, auditor independen berperan sebagai penengah kedua belah pihak (agen dan prinsipal) yang berbeda kepentingan. Tugas dari auditor diantaranya adalah memberikan pendapat atas kewajaran laporan keuangan. Dengan diaudit oleh auditor yang independen, agen dapat membuktikan bahwa kepercayaan prinsipal tidak diselewengkan untuk kepentingan pribadi agen. Dalam teori agensi, ada persepsi bahwa klien lebih percaya pada data yang diaudit oleh auditor bereputasi baik jika perusahaan telah diaudit oleh KAP yang berafiliasi dengan KAP Big Four yang dianggap memiliki kualitas yang baik.

Reputasi perusahaan audit yang melaksanakan pengauditan laporan keuangan tahunan berdasarkan pada apakah Kantor Akuntan Publik berafiliasi dengan Big Four atau tidak. Big Four akan cenderung lebih cepat dalam menyelesaikan pekerjaan audit yang mereka terima dibandingkan dengan Non Big Four. Hal ini dikarenakan bahwa kantor akuntan publik yang termasuk dalam Big Four, dapat melaksanakan auditnya dengan efisien dan memiliki jadwal waktu yang lebih fleksibel dalam menyelesaikan auditnya sehingga akan lebih menjaga, dan mempertahankan reputasi KAP (Anggradewi \& Haryanto, 2014)

$\mathrm{Ha}_{4}$ : Reputasi KAP berpengaruh negatif terhadap audit delay.

\section{Pengaruh Reputasi KAP dalam memperkuat Profitabilitas terhadap Audit Delay.}

Perusahaan dengan profitabilitas yang baik juga memiliki insentif lebih tinggi untuk menyelesaikan pekerjaan auditnya lebih cepat. Pengaruh profitabilitas pada audit delay dapat diperkuat dengan menggunakan jasa KAP yang memiliki reputasi baik yang cenderung menyelesaikan waktu audit lebih cepat sehingga akan memperpendek rentang audit delay.

Has: Reputasi KAP memperkuat pengaruh profitabilitas terhadap audit delay.

\section{Pengaruh Reputasi KAP dalam memperlemah Solvabilitas terhadap Audit Delay.}

Suatu perusahaan dengan solvabilitas yang tinggi berarti memiliki risiko keuangan yang tinggi karena mengalami kesulitan 
keuangan. Perusahaan akan meminta auditor untuk melakukan pengauditannya lebih lambat dari yang seharusnya sehingga terjadi ketidaktepatwaktuan dalam publikasi laporan keuangan (Handayani \& Wirakusuma, 2013). Dengan demikian, pemilihan KAP yang bermitra dengan The Big Four dilakukan agar dapat mengaudit secara lebih efisien dan efektif, serta memiliki fleksibilitas yang lebih tinggi agar dapat mengurangi ketidaktepatwaktuan dalam publikasi laporan keuangan. Besarnya ukuran Kantor Akuntan Publik diperlihatkan oleh tingginya kualitas yang dihasilkan dari jasanya yang selanjutnya akan berpengaruh pada jangka waktu penyelesaian audit. Waktu audit yang cepat merupakan salah satu cara KAP dengan kualitas tinggi untuk mempertahankan reputasi mereka

Ha6: Reputasi KAP memperlemah pengaruh solvabilitas terhadap audit delay.

\section{Pengaruh Reputasi KAP dalam memperkuat Ukuran Perusahaan terhadap Audit Delay.}

Perusahaan audit dengan reputasi Big Four cenderung mengurangi audit delay karena memiliki keuangan yang baik untuk mendapatkan sumber daya manusia dan material untuk menyelesaikan audit dalam waktu tertentu (Ilaboya \& Christian, 2014)). Kantor Akuntan Publik dengan reputasi yang baik cenderung memiliki sumber daya yang berkompeten untuk melaksanakan prosedur audit secara lebih efisien dan efektif sehingga laporan auditan dapat terselesaikan tepat waktu. Semakin besar ukuran perusahaan cenderung akan mempercepat proses penyusunan laporan keuangan yang membuat auditor memiliki waktu yang lebih banyak dalam pengauditannya. Pengaruh ukuran perusahaan pada audit delay akan semakin diperkuat dengan KAP yang memiliki reputasi baik karena memiliki penjadwalan yang fleksibel sehingga akan menghasilkan rentang audit delay yang pendek (Murti \& Widhiyani, 2016).

$\mathrm{Ha}_{7}$ : Reputasi KAP memperkuat pengaruh ukuran perusahaan terhadap audit delay.

\section{Metode Penelitian}

\section{Variabel Penelitian \\ 1. Variabel Dependen \\ Variabel dependen yang digunakan adalah audit delay, dimana menggunakan kategori total lag dalam pengukurannya. Lamanya total lag yang diukur berdasarkan jumlah hari dari tanggal tutup buku perusahaan, yaitu per 31 Desember sampai dengan tanggal penerimaan laporan keuangan audit dipublikasikan di bursa (Dyer \& McHugh, 1975). Variabel ini bersifat kuantitatif yang hasil akhirnya akan ditunjukkan dalam ukuran rata-rata audit delay dengan dipengaruhi oleh variabel independen yang akan dibahas lebih lanjut.}

\section{Variabel Independen}

(1) Profitabilitas

Profitabilitas merupakan kemampuan perusahaan mendapatkan hasil selama satu periode produksi. Dalam penelitian ini indikator yang digunakan untuk meningkatkan tingkat profitabilitas perusahaan adalah Return on Asset (ROA), rasio ini digunaan untuk mengukur kemampuan perusahaan menghasilkan keuntungan atau laba dengan aset yang tersedia. Menurut Asnawi dan Wijaya, (2015) profitabilitas perusahaan dengan rasio Return on Asset (ROA) dapat dihitung dengan rumus:

Return On Assets $=\frac{\text { Earning After Tax }(\text { EAT })}{\text { Total Assets }} \times 100 \%$

(2) Solvabilitas

Rasio solvabilitas merupakan rasio yang digunakan untuk mengukur kemampuan perusahaan untuk membayar semua utangnya, baik berupa utang jangka panjang maupun utang jangka pendek. Dalam penelitian ini, solvabilitas suatu perusahaan 
diukur dengan debt ratio (DR). Menurut Asnawi dan Wijaya, (2015) perhitungan solvabilitas dengan debt ratio (DR) dapat dihitung dengan rumus:

$$
\begin{aligned}
& \mathrm{DR}=\frac{\text { Total Liabilities }}{\text { Total Assets }} \\
& \times 100 \%
\end{aligned}
$$

(3) Ukuran Perusahaan

Estrini \& Laksito (2013), menyatakan ukuran perusahaan dapat dihitung menggunakan total asset. Total aset yang dimaksud adalah jumlah aset yang dimiliki perusahaan klien yang tercantum pada laporan keuangan perusahaan pada akhir periode yang telah diaudit. Dalam penelitian ini, ukuran perusahaan diukur dengan menggunakan logaritma natural dari total asset yang dimiliki perusahaan.

\section{Variabel Moderasi}

$\begin{array}{rrr} & \text { Variabel moderasi adalah } \\ \text { variabel yang mempengaruhi }\end{array}$ (memperkuat dan memperlemah) hubungan antara variabel independen dan dependen. Variabel ini disebut juga variabel independen kedua. Copper dan Pamela S. Schindler (2017: 65-66) menyatakan variabel moderator atau interaksi merupakan variabel bebas kedua yang dilibatkan karena diyakini memiliki kontribusi yang signifikan atau memiliki kesatuan pengaruh dalam hubungan independen variabel dan dependen variabel yang asli.

Variabel Reputasi KAP dalam penelitian ini merupakan variabel pemoderasi yang bersifat dummy. Perusahaan yang diaudit oleh KAP Big Four diberi kode (1) sedangkan perusahaan yang diaudit oleh KAP Non Big Four diberi kode (0).

\section{Teknik Pengumpulan Data}

Teknik pengumpulan data yang digunakan dalam penelitian ini adalah observasi, dimana peneliti melakukan pengamatan terhadap data sekunder dalam bentuk laporan keuangan yang telah diaudit (audited annual report) yang diterbitkan perusahaan public dan bersumber dari Bursa Efek Indonesia (www.idx.co.id) dan Indonesia Capital Market Directory tahun 2014-2016 yang diperoleh dari Pusat Data Pasar Modal Kwik Kian Gie School of Business. Objek penelitian yang digunakan adalah perusahaan pertambangan yang terdaftar di Bursa Efek Indonesia (BEI) dari tahun 2014-2016.

\section{Teknik Pengambilan Sampel}

Metode pengambilan sampel penelitian menggunakan purposive sampling. Kriteria-kriteria yang ditetapkan peneliti dalam penelitian ini adalah sebagai berikut: Perusahaan sampel yang digunakan adalah perusahaan pertambangan yang telah terdaftar pada Bursa Efek Indonesia (BEI) pada tahun 2014-2016, perusahaan pertambangan yang menerbitkan laporan keuangan auditan secara lengkap dengan tanggal per 31 Desember dan dipublikasikan berturutturut pada tahun 2014, 2015, dan 2016, mata uang dalam laporan keuangan adalah Rupiah, bila ada ketidaktersediaan data dari salah satu variabel pada perusahaan tertentu maka akan dikeluarkan dari sampel.

\section{Teknik Analisis Data}

Berikut ini adalah metode analisis data sebagai berikut:

\section{Analisis Statistik Deskriptif}

Analisis statistik deskriptif memberikan gambaran suatu data yang dilihat dari nilai rata-rata, standar deviasi, varian, maksimum, minimum, sum, range, kurtosis, dan skewness atau kemencengan distribusi (Ghozali, 2016:19). Pengukuran yang digunakan dalam penelitian ini adalah nilai maksimum, nilai minimum, nilai rata-rata (mean), dan standar deviasi. 
2. Uji Pooling

Pengujian ini dilakukan untuk mengetahui dapat atau tidaknya dilakukan penggabungan data penelitian (cross sectional dengan time series). Dengan menggunakan variabel dummy, pengujian dilakukan pada tingkat alpha $(\alpha=0,05)$ kriteria pengambilan keputusan ini adalah sebagai berikut:

a. Bila sig_dt $<0,05$ maka terdapat perbedaan koefisien dan tidak dapat dilakukan pooling. Maka pengujian data penelitian harus dilakukan per tahun.

b. Bila sig_dt $>0,05$ maka tidak terdapat perbedaan koefisien dan dapat dilakukan pooling. Maka pengujian data penelitian dapat dilakukan selama periode penelitian dalam 1 kali uji.

\section{Uji Asusmsi Klasik}

Sebelum melakukan pengujian regresi berganda, dalam penelitian ini terlebih dahulu dilakukan uji asumsi klasik yang terdiri dari uji normalitas, uji heteroskedastisitas, uji multikolonieritas, dan uji autokorelasi, sebelum melakukan pengujian hipotesis. Berikut ini penjelasan uji asumsi klasik yang digunakan (Ghozali, 2016).

\section{a. Uji Normalitas Data}

Dalam penelitian ini, uji nomalitas menggunakan uji statistic non-parametrik Kolmogorov-Smirnov (Uji K-S). menurut Ghozali (2016:30-31), uji K-S terlebih dahulu menentukan hipotesis pengujian dalam hipotesis nol dan hipotesis alternative (Ho dan $\mathrm{Ha}$ ). Pengujian dilakukan dengan menggunakan distribusi normal $(\alpha=5 \%)$ pada tingkat kepercayaan $95 \%$. Data yang baik adalah data yang dapat berdistribusi dengan normal.

b. Uji Multikolinearitas

Uji multikolinieritas bertujuan untuk menguji apakah model regresi ditemukan adanya korelasi antar variabel bebas (independen). Model regresi yang baik seharusnya tidak terjadi korelasi di antara variabel independen. Dasar pengambilan keputusan:

(1) Apabila nilai Tolerance $\geq$ 0,1 atau $\mathrm{VIF} \leq 10$, maka dapat disimpulkan tidak terjadi multikolinearitas.

(2) Apabila nilai Tolerance < 0,1 atau $\mathrm{VIF}>10$, maka dapat disimpulkan terjadi multikolinearitas.

\section{c. Uji Autokorelasi}

Salah satu cara untuk mengetahui ada tidaknya autokorelasi pada model regresi adalah dengan melakukan uji Run Test (Ghozali, 2016: 107). Uji Run Test merupakan bagian dari statistik non parametrik yang dapat digunakan untuk menguji apakah antar residual terdapat korelasi (Ghozali, 2016: 116). Berdasarkan Ghozali (2016: 117), dasar penentuan terjadinya autokorelasi atau tidak adalah:

a) Bila p-value $<0,05$ maka residual tidak random atau terjadi autokorelasi antar nilai residual

b) Bila p-value > 0,05 maka residual random atau tidak terjadi autokorelasi antar nilai residual

\section{d. Uji Heteroskedastisitas}

Uji heteroskedastisitas bertujuan menguji apakah dalam model regresi terjadi ketidaksamaan variance dari residual satu pengamatan ke pengamatan lain. Jika variance dari residual satu pengamatan ke pengamtan lain tetap, maka disebut homoskedastisitas dan jika berbeda disebut heteroskedastisitas. Model regresi yang baik adalah yang homoskedastisitas atau tidak terjadi heteroskedastisitas (Ghozali, 2016:134). Penelitian ini mengguunakan uji White dalam menguji 
heteroskedastisitas, dari persamaan regresi ini didapatkan nilai $\mathrm{R}$ Square untuk menghitung $\mathrm{c}^{2}$, dimana $\mathrm{c}^{2}=\mathrm{n} \times \mathrm{R}$ Square. Jika $\mathrm{c}^{2}$ hitung $<\mathrm{c}^{2}$ tabel, maka tidak terjadi heterokedastisitas dalam model.

\section{Moderated Regression Analysis}

Moderated Regression Analysis (MRA) dilakukan dengan membuat variabel interaksi, dimana variabel interaksi diperoleh dengan mengalikan variabel moderator dengan variabel independen. Menurut Ghozali (2016), moderated regression analysis menggunakan pendekatan analitik yang mempertahankan integritas sampel dan memberikan dasar untuk mengontrol pengaruh variabel moderator. Persamaan yang digunakan dalam penelitian ini adalah sebagai berikut:

$$
\begin{gathered}
\text { AUDEL }=\alpha+\beta_{1} \text { PROF }+\beta_{2} \text { SOLV }+\beta_{3} \\
\text { SIZE }+\beta_{4} \text { KAP }+\beta_{5} \text { PROF_KAP }+B_{6} \\
\text { SOLV_KAP }+ \\
\beta_{7} \text { SIZE_KAP }+\varepsilon
\end{gathered}
$$

\section{Pengujian Hipotesis}

Pengujian hipotesis yang dilakukan melalui:

a. Uji Koefisien Determinasi $\left(\mathbf{R}^{2}\right)$

Digunakan untuk mengukur seberapa besar kemampuan semua variabel independen dalam menjelaskan variabel dependennya. Jika nilainya mendekati satu semakin besar kemampuan variabel independen untuk menjelaskan variabel dependen (Ghozali, 2016:95). Cara menganalisisnya adalah sebagai berikut:

Jika $\mathrm{R}^{2}=0$, maka tidak ada hubungan antara variabel independen dengan variabel dependen atau model regresi yang terbentuk tidak tepat untuk meramalkan variabel dependennya (tidak ada hubungan antara $\mathrm{X}$ dengan $\mathrm{Y}$ ) Jika $\mathrm{R}^{2}=1$, maka ada hubungan antara variabel independen dengan variabel dependen atau model regresi yang terbentuk dapat meramalkan variabel dependen secara sempurna (ada hubungan antara X dengan $Y$ )

b. Uji Signifikansi Simultan (Uji F)

Menurut Ghozali (2016:96), uji F dilakukan untuk menunjukkan paakah semua variabel secara bersama-sama mempunyai pengaruh terhadap variabel dependen. Adapun kriteria pengujian:

(1) Jika Sig. $<\alpha(0,05)$, maka tolak Ho. Artinya, model regresi signifikan, semua variabel indpeenden secara simultan berpengaruh terhadap variabel dependen dan dapat digunakan untuk memprediksi variabel dependennya.

(2) Bila Sig. $\geq \alpha(0,05)$, maka tidak tolak Ho. Artinya, model regresi tidak signifikan, semua variabel indpeenden secara simultan tidak berpengaruh terhadap variabel dependen dan tidak dapat digunakan untuk memprediksi variabel dependennya.

c. Uji Signifikansi Parameter Individual (Uji t)

Uji $\mathrm{t}$ ini digunakan untuk mengetahui apakah variabel independen secara individual berpengaruh terhadap variabel dependen (Ghozali, 2016:97).

Dasar pengambilan keputusan:

(1) Jika p-value $<0,05$ dan thitung $>$ t-tabel, maka Ho ditolak yang berarti variabel yang diuji berpengaruh pada variabel dependen

(2) Jika p-value $>0,05$ dan thitung < t-tabel, maka Ho tidak ditolak yang berarti variabel yang diuji tidak berpengaruh pada variabel dependen. 


\section{Hasil Penelitian}

\section{Analisis Statistik Deskriptif}

Dalam hasil analisis statistik deskriptif pada tabel 1 dapat diketahui bahwa:

Variabel audit delay (AUDEL memiliki nilai minimum sebesar 27 dan nilai maksimum sebesar 146 yang artinya rentang audit delay pada perusahaan pertambangan paling cepat dilakukan adalah 27 hari yang dimiliki oleh PT Central Omega Resources Tbk dan paling lama dilakukan dalam 146 hari yaitu oleh PT Exploitasi Energi Indonesia Tbk, nilai rata-rata audit delay sebesar 94,23 (94 hari), dan nilai standar deviasi audit delay sebesar 23,041.

Profitabilitas memiliki nilai minimum -0,721 yang dimiliki oleh PT Mitra Investindo Tbk pada periode 2015 dan nilai maksimum 0,143 yang dimiliki oleh PT Bukit Asam Tbk pada periode 2014, serta rata-rata 0,0554 dengan standar deviasi 0,165 lebih besar dari rata-ratanya. Hal ini mengindikasikan bahwa penyebaran data untuk variabel profitabilitas dalam penelitian ini tidak merata atau terdapat perbedaan yang terlalu tinggi antara satu data dengan data yang lainnya.

Solvabilitas (SOLV) memiliki nilai minimum sebesar 0,041 dimiliki oleh PT Central Omega Resource Tbk pada periode 2015 dan nilai maksimum sebesar 0,647 dimiliki oleh PT Cita Mineral Investindo Tbk pada periode 2016. Rata-rata solvabilitas perusahaan dalam penelitian ini yaitu sebesar 0,427 dengan standar deviasi 0,14 lebih kecil dari rata-ratanya, dengan demikian penyebaran data untuk variabel solvabilitas dalam penelitian ini adalah merata atau tidak terdapat perbedaan yang terlalu tinggi antara satu data dengan data lainnya.

Ukuran perusahaan (SIZE) memiliki nilai minimum 25,784 dimiliki oleh PT Perdana Karya Perkasa Tbk pada periode 2016 dan nilai maksimum 30,553 dimiliki oleh PT Bukit Asam Tbk pada periode 2016. Nilai rata-rata ukuran perusahaan sebesar 28,31 dengan standar deviasi sebesar 1,411. Hal ini mengindikasikan bahwa ratarata perusahaan pertambangan di Indonesia cenderung termasuk ke dalam kategori perusahaan besar.

Interaksi Profitabilitas dengan reputasi KAP (PROF_KAP) memiliki nilai minimum $-0,08$ dan nilai maksimum 0,14. Rata-rata sebesar 0,0206. Variabel interaksi solvabilitas dengan reputasi KAP (SOLV_KAP) memiliki nilai minimum 0,000 dan nilai maksimum 0,45. Rata-rata sebesar 0,162. Variabel interaksi ukuran perusahaan dengan reputasi KAP (SIZE_KAP) memiliki nilai minimum 0,00 dan nilai maksimum 30,55 serta rata-rata sebesar 11,667. Hasil analisis statistik deskriptif pada variabel reputasi Kantor Akuntan Publik pada tabel 2 menunjukkan dari 30 sampel perusahaan, perusahaan yang diaudit oleh KAP Big Four (dummy 1) sebanyak 12 perusahaan atau sebesar $40 \%$ dari total sampel, sedangkan perusahaan yang diaudit oleh KAP Non Big Four (dummy 0) sebanyak 18 perusahaan atau sebesar $60 \%$ dari total sampel.

\section{Uji Pooling Data}

Bedasarkan hasil uji pooling data pada lampiran tabel 3, seluruh dummy mempunyai nilai Sig. diatas nilai pvalue ( > 0.05$)$, maka dapat disimpulkan bahwa data penelitian dapat di-pooling atau dapat digabungkan.

\section{Uji Asumsi Klasik}

a. Uji Normalitas

pengujian normalitas dengan program SPSS 20 menggunakan One Sample KolmogorovSmirnoc Test, pada lampiran tabel 4 diperoleh Asymp. Sig. (2-tailed) sebesar 0,859 > nilai p-value $(0,05)$, dimana berarti data berdistribusi normal.

b. Uji Multikolinearitas

Hasil pengujian untuk variabel profitabilitas, solvabilitas, ukuran perusahaan, dan reputasi KAP pada lampiran tabel 5 
diperoleh nilai VIF secara berturut-turut sebesar 2,007; 1,$203 ; 1,662 ; 1,525$; dimana seluruh variabel independen memiliki nilai VIF < 10. Hasil uji variabel profitabilitas, solvabilitas, ukuran perusahaan, dan reputasi KAP secara berturut-turut diperoleh nilai tolerance sebesar 0,$498 ; 0,831$; 0,$602 ; 0,656 ;$ dimana nilai tolerance dari semua variabel > 0,1 sehingga dapat disimpulkan bahwa model regresi yang terbentuk tidak terdapat korelasi antar variabel independen atau tidak terjadi multikolinearitas.

\section{c. Uji Autokorelasi}

Peneliti menggunakan Run Test pada SPSS 20 yang juga merupakan bagian dari statistic non-parametrik untuk menguji apakah antar residual terdapat korelasi. Berdasarkan tabel 6 diperoleh Asymp. Sig (2-tailed) sebesar 0,577 lebih besar dari nilai p-value $(0,05)$ maka residual random atau tidak terjadi autokorelasi antar nilai residual.

\section{d. Uji Heterokedastisitas}

Untuk mengetahui adanya heterokedastisitas atau tidak peneliti menggunakan uji White pada SPSS 20. Dari tabel 7 diperoleh nilai R Square sebesar 0,316 sehingga nilai $c^{2}$ hitung adalah 9,48 yang berasal dari jumlah sampel sebesar 30 dikalikan dengan nilai $\mathrm{R}^{2}$. Lalu nilai $\mathrm{c}^{2}$ tabel diperoleh melalui tabel chi-square, dimana peneliti menggunakan degree of freedom (df) sebesar 29 yang berasal dari jumlah objek yang diteliti dikurang 1 dengan nilai $\alpha$ sebesar 0,05 dan mendapatkan nilai $\mathrm{c}^{2}$ tabel sebesar 42,556. Dengan demikian, nilai $c^{2}$ hitung $<\mathrm{c}^{2}$ tabel maka dapat disimpulkan tidak terjadi heteroskedastisitas.

\section{Pengujian Hipotesis}

a. Uji Koefisien Determinasi

Berdasarkan hasil uji koefisien determinasi pada lampiran tabel 9 diperoleh nilai $\mathrm{R}$ Square sebesar 0,483 atau $48,3 \%$ yang berarti bahwa variabel audit delay dapat dijelaskan sebesar $48,3 \%$ oleh variabel profitabilitas, solvabilitas, ukuran perusahaan, dan reputasi Kantor Akuntan Publik dan sisanya sebesar $51,7 \%$ dijelaskan oleh variabel lain diluar model regresi yang digunakan.

b. Uji Signifikansi Simultan (Uji F)

Pengujian ini berguna untuk menguji kelayakan dari model penelitian, uji $\mathrm{F}$ dilakukan untuk menunjukkan apakah semua variabel independen secara bersama-sama mempunyai pengaruh terhadap variabel dependen. Berdasarkan hasil uji yang terdapat pada tabel 10, bahwa hasil sig. 0,025 artinya model regresi signifikan dan layak digunakan untuk memprediksi audit delay.

c. Uji Signifikansi Parameter Individual (Uji t)

Berdasarkan tabel 11, hasil uji $\mathrm{t}$ menunjukkan seberapa pengaruh masing-masing variabel independen secara individu menerangkan audit delay. Penelitian ini menggunakan $\alpha$ sebesar 0,05 dengan nilai $\mathrm{t}$ tabel sebesar $\pm 1,708$ dan penelitian ini dilakukan menggunakan satu sisi.

(1) Variabel profitabilitas (PROF) nilai koefisien regresi $\left(\beta_{1}\right)$ sebesar $-27,884$ yang artinya variabel profitabilitas memiliki hubungan negatif terhadap audit delay. Dimana nilai signifikansi uji $\mathrm{t}$ pada variabel profitabilitas diperoleh sebesar $0,376 / 2=0,188$ dimana nilai tersebut lebih besar dari nilai $\alpha(0,05)$. Hasil tersebut menunjukkan bahwa variabel profitabilitas berpengaruh negatif dan tidak signifikan terhadap audit delay. Artinya hipotesis 1 ditolak.

(2) Variabel solvabilitas (SOLV) memiliki nilai koefisien regresi $\left(\beta_{2}\right)$ sebesar 61,355 yang artinya variabel solvailitas memiliki 
hubungan positif terhadap audit delay. Nilai signifikan solvabilitas diperoleh sebesar $0,039 / 2=0,0195$ dimana nilai tersebut lebih kecil dari nilai $\alpha$ $(0,05)$ sehingga dapat disimpulkan bahwa variabel solvabilitas memiliki pengaruh positif dan signifikan terhadap audit delay, artinya hipotesis kedua diterima.

(3) Ukuran perusahaan (SIZE) memiliki nilai koefisien regresi $\left(\beta_{3}\right)$ sebesar 3,691 yang artinya variabel ukuran perusahaan memiliki hubungan positif terhadap audit delay. Nilai signifikan ukuran perusahaan diperoleh sebesar $0,369 / 2=0,184$ dimana nilai tersebut lebih besar dari nilai $\alpha(0,05)$ sehingga dapat disimpulkan bahwa variabel ukuran perusahaan memiliki pengaruh positif dan tidak signifikan terhadap audit delay.

(4) Variabel reputasi KAP (KAP) memiliki nilai koefisien regresi $\left(\beta_{4}\right)$ sebesar $-350,616$ yang artinya variabel reputasi KAP memiliki hubungan negatif terhadap audit delay. Nilai signifikan reputasi KAP diperoleh sebesar $0,171 / 2=0,085$ dimana nilai tersebut lebih besar dari nilai $\alpha(0,05)$ sehingga dapat disimpulkan bahwa variabel reputasi KAP memiliki pengaruh negatif dan tidak signifikan terhadap audit delay.

(5) Penelitian ini menggunakan variabel reputasi KAP sebagai variabel moderasi. Pengaruh reputasi KAP dalam memoderasi hubungan profitabilitas memiliki nilai $\beta$ sebesar $-435,632$ dan nilai signifikansi sebesar $0,011 / 2=$ 0,0055 yang berarti nilai tersebut lebih kecil dari $\alpha(0,05)$, serta diketahui pengaruh reputasi KAP terhadap audit delay memiliki nilai signifikan sebesar $0,085>\alpha$ $(0,05)$ sehingga dapat dikatakan bahwa reputasi KAP merupakan pure moderator yang memperkuat hubungan negatif antara profitabilitas terhadap audit delay secara signifikan.

(6) Pengaruh reputasi KAP dalam memoderasi hubungan solvabilitas terhadap audit delay memiliki nilai $\beta$ sebesar $-284,118$ dan nilai signifikan sebesar 0,07 yang berarti nilai tersebut lebih besar dari $\alpha(0,05)$, serta diketahui pengaruh reputasi KAP terhadap audit delay memiliki nilai signifikan sebesar $0,085>\alpha$ $(0,05)$ sehingga dapat disimpulkan bahwa reputasi KAP merupakan variabel moderator homologizer yang tidak mempengaruhi kekuatan hubungan antara solvabilitas terhadap audit delay, dan tidak berpengaruh terhadap audit delay secara signifikan.

(7) Pengaruh reputasi KAP dalam memoderasi hubungan ukuran perusahaan terhadap audit delay memiliki nilai $\beta$ sebesar 16,413 dan nilai signifikan sebesar 0,052 yang berarti nilai tersebut lebih besar dari $\alpha(0,05)$, serta diketahui pengaruh reputasi KAP terhadap audit delay memiliki nilai signifikan sebesar $0,085>\alpha$ $(0,05)$ sehingga dapat disimpulkan bahwa reputasi KAP merupakan variabel moderator homologizer yang tidak mempengaruhi kekuatan hubungan antara ukuran perusahaan terhadap audit delay, dan tidak berpengaruh terhadap audit delay secara signifikan.

\section{Pembahasan}

\section{Pengaruh Profitabilitas terhadap Audit Delay}

Berdasarkan hasil pengujian menyatakan bahwa profitabilitas berpengaruh negatif namun tidak signifikan terhadap audit delay dengan nlai koefisien regresi $\left(\beta_{1}\right)$ sebesar -27,884 dan sig. 0,188>0,05. Hasil ini tidak konsisten dengan hipotesis dalam penelitian ini, namun 
sesuai dengan pendapat Kartika (2009) yang dalam hasil penelitiannya menyatakan proses audit delay tidak dipengaruhi secara signifikan oleh tingkat profitabilitas perusahaan, hal ini dapat dikarenakan proses audit perusahaan yang memiliki tingkat profitabilitas kecil tidak berbeda dibandingkan proses audit perusahaan dengan tingkat profitabilitas yang besar. Perusahaan yang mengalami profitabilitas baik kecil maupun besar akan cenderung untuk mempercepat proses auditnya. Hal ini bertentangan dengan signalling theory yang menyatakan perusahaan yang memiliki profitabilitas tinggi akan menyampaikan laporan keuangan tepat waktu dan cenderung cepat memberikan sinyal kepada pangsa pasar karena manajemen perusahaan ingin meyakinkan bahwa perusahaan dalam posisi persaingan yang kuat dan memperlihatkan bahwa kinerja perusahaan baik.

2. Pengaruh Solvabilitas terhadap Audit Delay

Hasil penelitian menyatakan bahwa solvabilitas berpengaruh positif dan signifikan terhadap audit delay dengan nilai koefisien regresi $\beta_{2}$ sebesar 61,355 dan sig. $0,0195<0,05$. Hasil ini konsisten dengan hipotesis dalam penelitian ini dan sejalan dengan penelitian yang dilakukan oleh Ningsih \& Widhiyani (2015) yang menyatakan bahwa semakin banyak hutang yang diterima oleh perusahaan, maka semakin panjang audit delay. Proporsi hutang yang tinggi mengakibatkan perusahaan memperoleh sedikit masalah dimana perusahaan mau tidak mau harus mengkonfirmasi perolehan hutang yang dimiliki perusahaan kepada pihak-pihak terkait. Semakin besar hutang perusahaan akan semakin panjang proses yang harus dilakukan oleh pihak terkait dan secara otomatis penyusunan laporan audit akan semakin terhambat sehingga berdampak pada audit delay yang panjang. Besarnya hutang perusahaan merupakan bad news bagi perusahaan, maka hal ini sejalan dengan teori sinyal yang menyatakan bahwa bad news dianggap sebagai sinyal negatif sehingga tidak segera mempublikasikan laporan keuangannya. Terlambatnya mengumumkan laporan keuangan berkaitan dengan teori agensi bahwa agen dikatakan gagal mengumumkan penyampaian laporan keuangan tepat waktu.

3. Pengaruh Ukuran Perusahaan terhadap Audit Delay

Hasil penelitian menyatakan bahwa ukuran perusahaan berpengaruh positif namun tidak signifikan terhadap audit delay. Hasil ini tidak konsisten dengan hipotesis dalam penelitian dan tidak sejalan dengan penelitian Ningsih \& Widhiyani (2015) yang menyatakan semakin besar ukuran perusahaan maka semakin pendek audit delay. Besarnya total asset yang dimiliki suatu perusahaan mencerminkan bahwa perusahaan tersebut memiliki sistem pengendalian internal yang baik sehingga perusahaan besar seringkali memiliki audit internal yang baik yang mengharuskan perusahaan dimonitori secara ketat oleh para investor agar proses penyusunan laporan audit dapat diselesaikan dengan rentang waktu sesingkat mungkin.

Hasil penelitian sejalan yang dilakukan oleh Anggradewi \& Haryanto (2014) yang menyatakan bahwa hasil yang tidak signifikan dari variabel ukuran perusahaan terhadap audit delay dalam penelitian ini, disebabkan adanya penggunaan sampel dalam penelitian ini yang menggunakan keseluruhan perusahaan yang terdaftar di Bursa Efek Indonesia sehingga memiliki kesamaan dalam hal pengawasan dari investor, regulator, dan sorotan masyarakat, maka hal ini memungkinkan bahwa perusahaan dengan total aset besar maupun kecil memiliki internal control yang baik dan memiliki kemampuan untuk 
menekan auditornya agar dapat menyelesaikan pekerjaan audit secara tepat waktu.

4. Pengaruh Reputasi Kantor Akuntan Publik terhadap Audit Delay

Hasil penelitian menyatakan bahwa reputasi kantor akuntan publik memiliki pengaruh negatif dan tidak signifikan terhadap audit delay dengan nilai koefisien regresi $\beta_{4}$ sebesar $-350,616$ dan sig. $0,085>$ 0,05 . Hasil ini tidak konsisten dengan hipotesis dalam penelitian ini. Hasil ini tidak sejalan dengan teori agensi dengan persepsi bahwa klien lebih percaya pada data yang diaudit oleh auditor bereputasi baik yaitu KAP yang berafiliasi dengan KAP Big Four.

Hasil penelitian ini mendukung penelitian Febrianty (2011) yang menyatakan bahwa semakin baik reputasi KAP maka KAP tersebut belum memberikan jaminan terhadap kualitas audit yang dilakukan dengan salah satunya yakni ketepatan waktu dalam menyampaikan laporan keuangan, dimana seharusnya semakin besar KAP, semakin banyak memiliki sumber daya, lebih banyak auditor ahli dan sistem informasi yang canggih serta memiliki sistem kerja audit yang baik sehingga akan semakin cepat dalam penyelesaian laporan keuangan.

5. Pengaruh Reputasi KAP dalam Memperkuat Hubungan antara Profitabilitas terhadap Audit Delay

Hasil penelitian membuktikan bahwa reputasi KAP memperkuat hubungan antara profitabilitas terhadap audit delay dengan koefisien regresi $\left(\beta_{5}\right)$ sebesar $-435,632$ dan sig. $0,005<0,05$. Hasil penelitian ini reputasi KAP memperkuat hubungan negatif profitabilitas terhadap audit delay. Hal ini konsisten dengan hipotesis penelitian. Reputasi KAP mampu memperkuat hubungan antara profitabilitas pada audit delay yaitu sama-sama memperpendek audit delay. Hal ini disebabkan karena perusahaan dengan profitabilitas yang baik juga memiliki insentif lebih tinggi untuk menyelesaikan pekerjaan auditnya lebih cepat. Kantor akuntan publik akan memberikan pelayanan terbaik untuk menjaga kepercayaan dan kepuasan kliennya dan bekerja sesuai dengan kontrak kerjasama yang sebelumnya dibuat. Hal ini menunjukkan bahwa reputasi KAP yang baik akan memberikan pelayanan terbaik untuk dapat menjaga kepercayaan kliennya.

Hal ini sejalan dengan penelitian Handayani \& Wirakusuma (2013) yang menyatakan perusahaan dengan profitabilitas yang baik juga memiliki insentif lebih tinggi untuk menyelesaikan pekerjaan auditnya lebih cepat. Saat perusahaan mengalami profitabilitas yang tinggi, manajemen perusahaan justru akan semakin cepat dalam menyajikan laporan keuangannya sehingga pengaudian laporan keuangan oleh kantor akuntan publik pun tidak mengalami keterlambatan dan perusahaan justru akan tepat waktu dalam mempublikasikan laporan keuangannya.

6. Pengaruh Reputasi KAP dalam Memperlemah Hubungan antara Solvabilitas terhadap Audit Delay

Hasil penelitian membuktikan bahwa reputasi KAP tidak berpengaruh signifikan dalam memperlemah hubungan antara solvabilitas terhadap audit delay dengan nilai koefisien regresi $\left(\beta_{6}\right)$ sebesar -284,118 dan sig. 0,07>0,05. Sehingga dapat disimpulkan bahwa reputasi KAP bukanlah variabel moderasi yang mampu memperkuat dan memperlemah hubungan antara solvabilitas terhadap audit delay dimana hasil penelitian ini tidak konsisten dengan hipotesis dalam penelitian ini. Hal ini ditunjukkan oleh kualitas KAP di Indonesia memang sudah baik, dibuktikan dengan surat ijin KAP yang diterbitkan oleh kementerian keuangan Republik Indonesia. Maka dari itu setiap KAP yang berafiliasi dengan Big Four ataupun selain yang 
berafiliasi dengan Big Four memiliki kualitas yang sama. Auditor yang ditunjuk oleh KAP tersebut pasti telah menyediakan waktu yang sesuai dengan kebutuhan jangka waktu untuk menyelesaikan proses pengauditan hutang perusahaan dan senantiasa selalu berusaha untuk menjaga reputasinya dimata klien dalam menyelesaikan proses audit tepat waktu.

7. Pengaruh Reputasi KAP dalam Memperkuat Hubungan antara Ukuran Perusahaan terhadap Audit Delay

Hasil penelitian membuktikan bahwa reputasi KAP tidak berpengaruh signifikan dalam memperkuat hubungan antara ukuran perusahaan terhadap audit delay dengan nilai koefisien regresi $\left(\beta_{7}\right)$ sebesar 16,413 dan sig. 0,052>0,05. Sehingga dapat disimpulkan bahwa reputasi KAP bukanlah variabel moderasi yang mampu memperkuat hubungan antara ukuran perusahaan terhadap audit delay.

Hasil penelitian ini tidak konsisten dengan hipotesis dalam penelitian ini. Sebuah KAP baik yang berafiliasi dengan Big Four atau Non Big Four, yang melaksanakan prosedur audit bagi perusahaan baik yang memiliki total aset besar maupun kecil tidak akan mempengaruhi proses penyelesaian audit laporan keuangan, karena auditor yang ditunjuk oleh KAP tersebut pasti telah menyediakan waktu yang sesuai dengan kebutuhan jangka waktu untuk menyelesaikan proses pengauditan aset perusahaan. KAP yang berafiliasi dengan Big Four maupun KAP Non Big Four senantiasa selalu berusaha untuk menjaga kualitas hasil auditnya yang diantaranya adalah memenuhi ketepatan waktu agar KAP mereka tetap dapat dipercaya klien.

\section{Kesimpulan dan Saran}

Kesimpulan dari hasil penelitian ini adalah terdapat cukup bukti solvabilitas berpengaruh positif terhadap audit delay dan reputasi kantor akuntan publik memperkuat pengaruh profitabilitas terhadap audit delay. Tidak terdapat cukup bukti profitabilitas, ukuran perusahaan, dan reputasi kantor akuntan publik berpengaruh negatif terhadap audit delay, dan tidak terdapat cukup bukti reputasi kantor akuntan publik memperlemah pengaruh solvabilitas terhadap audit delay dan memperkuat pengaruh ukuran perusahaan terhadap audit delay.

Berdasarkan keterbatasan diatas, maka penulis memberikan beberapa saran untuk penelitian selanjutnya, yaitu: Reputasi KAP dapat dijadikan sebagai variabel intervening, menggunakan proxy yang berbeda dari penelitian ini seperti report lag untuk variabel audit delay, serta menggunakan atau menambah variabel penelitian selain dari penelitian ini agar dapat digunakan sebagai bahan perbandingan, menggunakan sektor perusahaan selain pertambangan, seperti sektor perbankan, sektor keuangan, dan sektor lainnya agar lebih dapat dibandingkan keterlambatan pelaporan keuangan yang terjadi.

\section{Daftar Pustaka}

Anggradewi, Annurrizky, Haryanto (2014). Analisis Faktor-Faktor Yang Mempengaruhi Audit Delay. Diponegoro Journal of Accounting, Vol. 3, No.2.

Angruningrum, S., Made Gede Wirakusuma (2013). Pengaruh Profitabilitas, Leverage, Kompleksitas Operasi, Reputasi KAP dan Komite Audit Pada Audit Delay. E-Jurnal Akuntansi Universitas Udayana.

Apriani, S., Basuki Toto (2017). Analisis Pengaruh Profitabilitas, Ukuran Perusahaan Dan Ukuran Kantor Akuntan Publik ( Kap ) Terhadap Audit Delay Pada Perusahaan Pertambangan Periode 2010 2014. Jurnal Riset Manajemen dan Bisnis (JRMB) Fakultas Ekonomi UNIAT, Vol. 2.

Asnawi, Said K., Chandra Wijaya (2015). FINON (Finance for Non Finance) 
Manajemen Keuangan untuk Non Keuangan, Jakarta: Rajawali Pers.

Budiartha, I Ketut, Ni Nengah D. A (2014). Pengaruh Total Aset, Tingkat Solvabilitas Dan Opini Audit Pada Audit Delay, E-Jurnal Akuntansi Universitas Udayana.

Cooper, Donald R., Pamela S. Schinder (2014), Business Research Methods, Vol. 12, International Edition, Singapura: McGraw-Hill.

Dyer, James C., Arthur J. Mchugh (1975) The Timeliness of the Australian Annual Report, Journal of Accounting Research, Vol. 13, No. 2

Estrini, Dwi Hayu, Herry Laksito (2013). Analisis Faktor-Faktor yang mempengaruhi Audit Delay (Studi Empiris Pada Perusahaan Manufaktur yang terdaftar di BEI Tahun 2009-2011). Diponegoro Journal Of Accounting. Vol. 2, No. 2.

Febrianty, Faktor-Faktor Yang Berpengaruh Terhadap Audit Delayperusahaan Sektor Perdagangan Yang Terdaftar Di Bei Periode 20072009, Jurnal Ekonomi Dan Informasi Akuntansi, Vol. 1, No. 3.

Handayani, Ade Putri., Made Gede Wirakusuma (2013). Pengaruh Profitabilitas, Solvabilitas, Reputasi Kantor Akuntan Publik Pada Ketidaktepatwaktuan Publikasi Laporan Keuangan Perusahaan Di BEI, E-Jurnal Akuntansi Universitas Udayana.

Ilaboya, O. J., Iyafekhe Christian (2014). Corporate Governance and Audit Report Lag in Nigeria, The Timeliness of the Australian Annual Report. Journal of Accounting Research.
Ghozali, Imam (2016). Aplikasi Analisis Multivariate dengan Program IBM SPSS 23, Semarang: Badan Penerbit Universitas Dipenogoro.

Jensen, Michael C., William H. Meckling (1976), Theory of the Firm: Managerial Behaviour, Agency Costs and Ownership Structure, Journal of Financial Economics, Vol. 3, No.4.

Kartika, Andi (2009). Faktor-Faktor yang Mempengaruhi Audit Delay di Indonesia (Studi Empiris pada Perusahaan-Perusahaan LQ 45 yang Terdaftar di Bursa Efek Jakarta). Jurnal Bisnis Dan Ekonomi, Vol 16, No. 1.

Lianto, Novice, Budi Hartono (2010). FaktorFaktor Yang Berpengaruh Terhadap Audit Report Lag. Jurnal Bisnis Dan Akuntansi, Vol. 12, No. 2.

Lucyanda, Jurica, Sabrina Paramitha (2013). Pengujian Faktor-Faktor Yang Memengaruhi Audit Delay. Jurnal Akuntansi \& Auditing Vol. 9, No. 2.

Melani, A 2016, Belum Sampaikan Laporan Tahunan, BEI Beri Sanksi ke 63 Emiten, Liputan 6, diakses 8 Oktober 2018, https://www.liputan6.com/bisnis/r ead/2532990/belum-sampaikanlaporan-tahunan-bei-beri-sanksike-63-emiten

Murti, N. M. D. A., Ni Luh S. W. (2016). Pengaruh Ukuran Perusahaan Dan Profitabilitas Pada Audit Delay Dengan Reputasi Kap Sebagai Variabel Pemoderasi. EJurnal Akuntansi Universitas Udayana, Vol.16.1.

Nabhani, A 2015, Payah, 52 Emiten Telat Laporkan Keuangan, Harian Eknomi Neraca, diakses 8 Oktober 2018, http://www.neraca.co.id/article/52 
481/payah-52-emiten-telatlaporkan-keuangan

Ningsih, I Gusti A. P. S., Ni Luh S. W. (2015). Pengaruh Ukuran Perusahaan, Laba Operasi, Solvabilitas, Dan Komite Audit Pada Audit Delay. E-Jurnal Akuntansi Universitas Udayana, Vol. 12, No. 3

Peraturan Bapepam dan LK Nomor X.K.2 Tentang Penyampaian Laporan Keuangan Berkala Emiten Atau Perusahaan Publik. Kep346/BL/2011.

Puspitasari, Elen, Anggraeni N. S. (2012). Pengaruh Karakteristik Perusahaan Terhadap Lamanya
Waktu Penyelesaian Audit (Audit Delay) Pada Perusahaan Manufaktur Yang Terdaftar Di Bursa Efek Indonesia. Jurnal Akuntansi \& Auditing, Vol. 9, No. 1

Rachmawati, Sistya (2008). Pengaruh Faktor Internal dan Eksternal Perusahaan Terhadap Audit Delay dan Timeliness. Jurnal Akuntansi Dan Keuangan, Vol. 10, No. 1.

Ross, S. A. (1977). The Determination of Financial Structure: The Incentive Signalling Approach. Bell Journal of Economics, Vol. 8 No. 1. 


\section{LAMPIRAN}

\section{Tabel 1}

\section{Statistik Deskriptif}

Descriptive Statistics

\begin{tabular}{|l|r|r|r|r|r|}
\hline & $\mathrm{N}$ & Minimum & Maximum & \multicolumn{1}{c|}{ Mean } & Std. Deviation \\
\hline AUDEL & 30 & 27 & 146 & 94,23 & 23,041 \\
PROF & 30 &,- 721 &, 143 &,- 05540 &, 165394 \\
SOLV & 30 &, 041 &, 647 &, 42766 &, 140403 \\
SIZE & 30 & 25,784 & 30,553 & 28,31860 & 1,411660 \\
PROFxKAP & 30 &,- 08 &, 14 &, 0206 &, 04922 \\
SOLVxKAP & 30 &, 000 &, 450 &, 16224 &, 203358 \\
SIZExKAP & 30 &, 00 & 30,55 & 11,6676 & 14,55480 \\
Valid N (listwise) & 30 & & & & \\
\hline
\end{tabular}

Sumber: Output SPSS 20

Tabel 2

Statistik Deskriptif Reputasi Kantor Akuntan Publik

\begin{tabular}{|c|c|c|c|c|c|}
\hline \multicolumn{6}{|c|}{ KAP } \\
\hline & & Frequency & Percent & Valid Percent & $\begin{array}{c}\text { Cumulative } \\
\text { Percent }\end{array}$ \\
\hline \multirow{3}{*}{ Valid } & 0 & 18 & 60,0 & 60,0 & 60,0 \\
\hline & 1 & 12 & 40,0 & 40,0 & 100,0 \\
\hline & Total & 30 & 100,0 & 100,0 & \\
\hline
\end{tabular}

Sumber: Output SPSS 20 
Tabel 3

Pooling Data

Coefficients $^{\mathbf{a}}$

\begin{tabular}{|c|c|c|c|c|c|c|}
\hline \multirow{2}{*}{\multicolumn{2}{|c|}{ Model }} & \multicolumn{2}{|c|}{ Unstandardized Coefficients } & \multirow{2}{*}{$\begin{array}{c}\begin{array}{c}\text { Standardized } \\
\text { Coefficients }\end{array} \\
\text { Beta }\end{array}$} & \multirow[t]{2}{*}{$\mathrm{t}$} & \multirow[t]{2}{*}{ Sig. } \\
\hline & & B & Std. Error & & & \\
\hline \multirow{18}{*}{1} & (Constant) & $-126,627$ & 151,487 & &,- 836 & , 420 \\
\hline & PROF & $-51,419$ & 86,596 &,- 369 &,- 594 &, 564 \\
\hline & SOLV & 33,941 & 46,523 &, 207 & ,730 & ,480 \\
\hline & SIZE & 7,776 & 5,471 & ,476 & 1,421 & , 181 \\
\hline & KAP & $-194,119$ & 238,901 & $-4,198$ &,- 813 & ,432 \\
\hline & PROFxKAP & $-322,273$ & 151,994 &,- 688 & $-2,120$ & ,056 \\
\hline & SOLVxKAP & $-209,467$ & 192,359 & $-1,849$ & $-1,089$ & ,298 \\
\hline & SIZExKAP & 8,874 & 9,510 & 5,606 & ,933 & ,369 \\
\hline & DT1 & $-90,437$ & 237,081 & $-1,882$ &,- 381 &, 710 \\
\hline & DT2 & 196,910 & 183,675 & 4,098 & 1,072 & ,305 \\
\hline & PROFDT1 & $-6,615$ & 103,408 &,- 043 &,- 064 & ,950 \\
\hline & SOLVDT1 & 100,402 & 65,961 & ,975 & 1,522 & , 154 \\
\hline & SIZEDT1 & ,802 & 8,541 & ,473 & ,094 & ,927 \\
\hline & KAPDT1 & 42,487 & 22,204 & ,638 & 1,913 & ,080 \\
\hline & PROFDT2 & 120,875 & 158,019 & ,288 & ,765 & ,459 \\
\hline & SOLVDT2 & $-9,451$ & 83,067 &,- 100 &,- 114 & ,911 \\
\hline & SIZEDT2 & $-6,921$ & 6,569 & $-4,083$ & $-1,054$ & ,313 \\
\hline & KAPDT2 & 23,440 & 26,839 &, 352 &, 873 & ,400 \\
\hline
\end{tabular}

a. Dependent Variable: AUDEL

Sumber: Output SPSS 20 


\section{Hasil Uji Asumsi Klasik}

Tabel 4

\section{Uji Normalitas}

\begin{tabular}{|ll|r|}
\hline \multicolumn{2}{|c|}{ One-Sample Kolmogorov-Smirnov Test } \\
\hline $\mathrm{N}$ & & $\begin{array}{c}\text { Unstandardize } \\
\text { d Residual }\end{array}$ \\
Normal Parameters ${ }^{\mathrm{a}, \mathrm{b}}$ & Mean & 30 \\
& Std. Deviation & $0 \mathrm{E}-7$ \\
& Absolute & $, 16,56103882$ \\
Most Extreme Differences & Positive &, 110 \\
& Negative &,- 079 \\
Kolmogorov-Smirnov Z & &, 604 \\
Asymp. Sig. (2-tailed) & &, 859 \\
\hline
\end{tabular}

a. Test distribution is Normal.

b. Calculated from data.

Tabel 5

\section{Uji Multikolinearitas}

\begin{tabular}{|c|c|c|c|c|c|c|c|c|}
\hline \multicolumn{9}{|c|}{ Coefficients $^{a}$} \\
\hline \multirow{2}{*}{\multicolumn{2}{|c|}{ Model }} & \multicolumn{2}{|c|}{$\begin{array}{c}\text { Unstandardized } \\
\text { Coefficients }\end{array}$} & \multirow{2}{*}{$\begin{array}{c}\begin{array}{c}\text { Standardized } \\
\text { Coefficients }\end{array} \\
\text { Beta }\end{array}$} & \multirow[t]{2}{*}{$\mathrm{t}$} & \multirow[t]{2}{*}{ Sig. } & \multicolumn{2}{|c|}{ Collinearity Statistics } \\
\hline & & $\mathrm{B}$ & Std. Error & & & & Tolerance & $\mathrm{VIF}$ \\
\hline \multirow{5}{*}{1} & (Constant) & 1,022 & 99,296 & & 010 & ,992 & & \\
\hline & PROF & $-44,088$ & 33,404 &,- 316 & $-1,320$ & 199 & ,498 & 2,007 \\
\hline & SOLV & 52,800 & 30,462 & ,322 & 1,733 &, 095 & ,831 & 1,203 \\
\hline & SIZE & 2,482 & 3,562 & ,152 & 697 & ,492 & ,602 & 1,662 \\
\hline & KAP & $-5,227$ & 9,664 &,- 113 &,- 541 & ,593 & 656 & 1,525 \\
\hline
\end{tabular}

a. Dependent Variable: AUDEL 
Tabel 6

Uji Autokorelasi

\begin{tabular}{|l|r|}
\hline \multicolumn{2}{|c}{ Runs Test } \\
\hline & $\begin{array}{c}\text { Unstandardize } \\
\text { d Residual }\end{array}$ \\
\hline Test Value & a \\
Cases < Test Value &,- 33053 \\
Cases >= Test Value & 15 \\
Total Cases & 15 \\
Number of Runs & 30 \\
Z & 14 \\
Asymp. Sig. (2-tailed) &,- 557 \\
\hline
\end{tabular}

a. Median

Tabel 7

\section{Uji Heteroskedastisitas}

Model Summary

\begin{tabular}{|l|r|r|r|r|}
\hline Model & \multicolumn{1}{|c|}{$\mathrm{R}$} & R Square & $\begin{array}{c}\text { Adjusted R } \\
\text { Square }\end{array}$ & $\begin{array}{c}\text { Std. Error of } \\
\text { the Estimate }\end{array}$ \\
\hline 1 &, $562^{\mathrm{a}}$ &, 316 &, 099 & 10,48206 \\
\hline
\end{tabular}

a. Predictors: (Constant), SIZExKAP, SOLV, SIZE, PROFxKAP, PROF, SOLVXKAP, KAP 
Tabel 8

Hasil Moderated Regression Analysis (MRA)

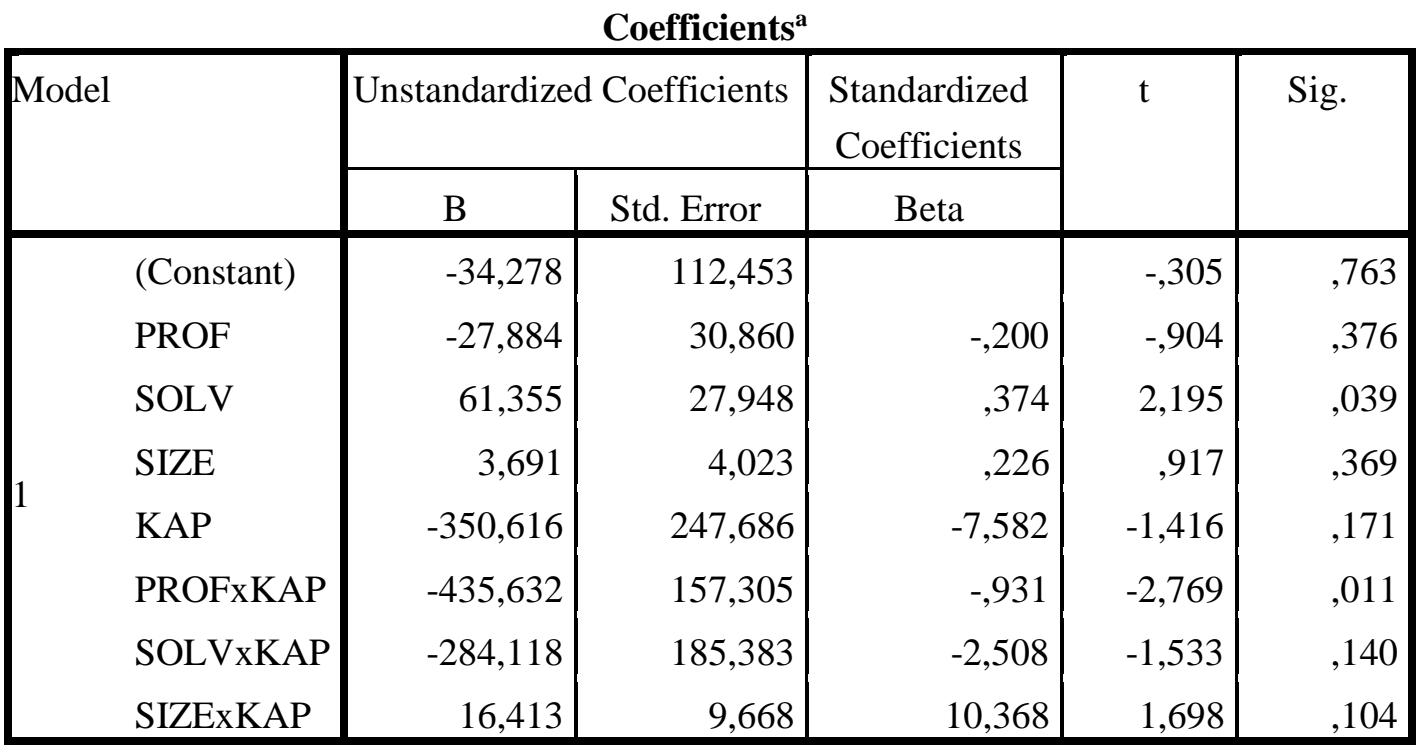

a. Dependent Variable: AUDEL

Tabel 9

Hasil Uji Koefisien Determinasi

Model Summary

\begin{tabular}{|l|r|r|r|r|}
\hline Model & \multicolumn{1}{|c|}{$\mathrm{R}$} & R Square & \multicolumn{1}{c|}{$\begin{array}{c}\text { Adjusted R } \\
\text { Square }\end{array}$} & $\begin{array}{c}\text { Std. Error of } \\
\text { the Estimate }\end{array}$ \\
\hline 1 &, $695^{\mathrm{a}}$ &, 483 &, 319 & 19,014 \\
\hline
\end{tabular}

a. Predictors: (Constant), SIZExKAP, SOLV, SIZE, PROFxKAP, PROF, SOLVxKAP, KAP

Tabel 10

Hasil Uji F

ANOVA $^{\mathrm{a}}$

\begin{tabular}{|c|c|c|c|c|c|c|}
\hline \multicolumn{2}{|c|}{ Model } & $\begin{array}{l}\text { Sum of } \\
\text { Squares }\end{array}$ & $\mathrm{df}$ & Mean Square & $\mathrm{F}$ & Sig. \\
\hline \multirow{3}{*}{1} & Regression & 7441,594 & 7 & 1063,085 & 2,940 &, $025^{\mathrm{b}}$ \\
\hline & Residual & 7953,772 & 22 & 361,535 & & \\
\hline & Total & 15395.367 & 29 & & & \\
\hline
\end{tabular}

a. Dependent Variable: AUDEL

b. Predictors: (Constant), SIZExKAP, SOLV, SIZE, PROFxKAP, PROF, SOLVxKAP, KAP 
Tabel 11

\section{Hasil Uji T}

Coefficients $^{\mathrm{a}}$

\begin{tabular}{|c|c|c|c|c|c|c|}
\hline \multirow{2}{*}{\multicolumn{2}{|c|}{ Model }} & \multicolumn{2}{|c|}{ Unstandardized Coefficients } & \multirow{2}{*}{$\begin{array}{c}\text { Standardized } \\
\text { Coefficients } \\
\text { Beta }\end{array}$} & \multirow[t]{2}{*}{$\mathrm{t}$} & \multirow{2}{*}{ Sig. } \\
\hline & & B & Std. Error & & & \\
\hline \multirow{8}{*}{1} & (Constant) & $-34,278$ & 112,453 & &,- 305 & ,763 \\
\hline & PROF & $-27,884$ & 30,860 &,- 200 &,- 904 & ,376 \\
\hline & SOLV & 61,355 & 27,948 & ,374 & 2,195 & ,039 \\
\hline & SIZE & 3,691 & 4,023 & ,226 & ,917 & ,369 \\
\hline & KAP & $-350,616$ & 247,686 & $-7,582$ & $-1,416$ &, 171 \\
\hline & PROFxKAP & $-435,632$ & 157,305 &,- 931 & $-2,769$ & ,011 \\
\hline & SOLVxKAP & $-284,118$ & 185,383 & $-2,508$ & $-1,533$ &, 140 \\
\hline & SIZExKAP & 16,413 & 9,668 & 10,368 & 1,698 & ,104 \\
\hline
\end{tabular}

a. Dependent Variable: AUDEL 